pp. 7-19

\author{
Anna DUDA-ŁYSZCZYK
}

ORCID: 0000-0002-9513-0080

Dolnośląska Szkoła Wyższa

we Wroctawiu

\title{
Przygotowanie dzieci do podjęcia nauki w szkole w refleksji początkującego nauczyciela
}

\begin{abstract}
Preparing children to start school at the reflection of a beginner teacher
The article discusses the work of a young teacher who starts his professional career from a grade zero. Teachers are subject to certain restrictions and are required to comply with the legal provisions laid down by statutes. Starting work as a teacher prompts reflection on the choice of methods and forms of work, taking into account the teacher's obligations set out in legal acts. A teacher working in a kindergarten should prepare children to enter school so that they can master reading and writing skills in the future. Referring to the theory of a reflective teacher, I tried to consider the professional development of a teacher who is looking for the best method of work for him, and thus creates his own method of shaping phonological awareness in children. This method is an original reconstruction of J. Reichen's reading method. The article presents both the theoretical assumptions of his method and notes from the observation carried out during the introduction of innovations to the preschool group. I also try to answer the question, how does the introduction of innovations affect the professional development of the teacher and the development of children?
\end{abstract}

Keywords: preschool education, professional development, teacher, phonological awareness, reading method

Słowa kluczowe: edukacja przedszkolna, rozwój zawodowy, nauczyciel, świadomość fonologiczna, metoda czytania

\section{Wprowadzenie}

Zawód nauczyciela jest związany $\mathrm{z}$ wieloma zadaniami i wyzwaniami wobec zmieniającej się sytuacji społecznej. $Z$ własnego doświadczenia wiem, że młodzi nauczyciele, często pełni zapału do pracy, zderzają się z rzeczywistością, której 
nie wyjaśniają podręczniki akademickie. Zarówno specyfika placówki, różnorodność problemów, z którymi borykają się dzieci, ich rodzice oraz inni nauczyciele, jak i konieczność współpracy z osobami, które często mają inny pogląd na edukację i wychowanie, stawiają nauczycieli w trudnej sytuacji, wymagającej głębokiej refleksji na temat wyznawanych przez siebie pedagogicznych ideałów.

Ponadto praca nauczyciela wiąże się z respektowaniem pewnych przepisów prawnych określonych w ustawach. Zadania i obowiązki nauczyciela są zawarte w Karcie Nauczyciela (Ustawa z 26 stycznia 1982 r.) oraz w Ustawie z 7 września 1991 r. o systemie oświaty, natomiast treści nauczania i umiejętności określa Podstawa programowa wychowania przedszkolnego dla przedszkoli, oddziałów przedszkolnych w szkołach podstawowych oraz innych form wychowania przedszkolnego. Każdy nauczyciel jest zobligowany do wywiązywania się z treści zawartych w powyższych aktach prawnych. Jako młody nauczyciel na początku swojej kariery zawodowej dokładnie zapoznałam się z tymi dokumentami, a także statutem mojej placówki, rocznym planem pracy oraz planem współpracy z rodzicami. Swój rozwój pojmowałam jako naturalną kolej rzeczy, zgodnie z odgórnie określonymi wytycznymi. Nigdy się nie zastanawiałam, jak różne czynniki mogą wpływać na mnie jako nauczyciela. Wdrażanie się do codziennej pracy, szukanie swojego stylu oraz zmieniające się relacje $z$ moimi podopiecznymi wzbudziły we mnie refleksję na temat źródła tych zmian.

Zaczęłam zatem zastanawiać się nad własnym rozwojem zawodowym, rozumianym jako „wszelki długotrwały proces kierunkowych zmian, w którym można wyróżnić prawidłowo po sobie następujące etapy przemian danego obiektu, wykazujące stwierdzalne zróżnicowanie się tego obiektu pod określonym względem" (Gerlach, 2014, s. 3-6). Poszukiwałam drogi zarówno własnego rozwoju, jak i edukacji dzieci. Postawiłam sobie za cel być nauczycielem refleksyjnym, takim, dla którego dobro dziecka jest najważniejsze, a jego potrzeby i możliwości wyznaczają metody i formy pracy.

\section{Metody nauki czytania}

Moim obowiązkiem jako nauczyciela przedszkola w klasie zerowej jest przygotowanie dzieci do nauki czytania i pisania, a zatem powinnam być ekspertem know-how, i to na bazie wiedzy teoretycznej (Gołębniak, 1998, s. 18). W tym wypadku wiąże się to $\mathrm{z}$ wiedzą na temat przygotowania dzieci do nauki czytania i pisania, rozwoju słuchu fonematycznego i świadomości fonologicznej (Krasowicz-Kupis, 2004, s. 18). Według D. Gołębniak „być profesjonalistą to znaczy demonstrować działania, które są nie tylko efektywne, ale i zgodne z tradycją danej profesji”. Moje działania są ściśle związane $z$ dążeniem do osiągnię- 
cia przez dzieci gotowości szkolnej, która współcześnie jest rozpatrywana w kategoriach interakcyjnych, to znaczy ujmuje się ją dynamicznie jako efekt „współgrania” właściwości dziecka i właściwości ofert edukacyjnych (Marek, 2003, s. 56-60), oczywiście uwzględniając indywidualne potrzeby i możliwości ucznia. Przygotowując się do zawodu nauczyciela, poznałam obszerną metodykę nauki czytania i pisania, różne kwalifikacje metod oraz eksperymentalne metody nauki czytania. Obecnie przyjmuje się, że najczęściej stosowana klasyfikacja metod nauki czytania obejmuje cztery podstawowe grupy: metody syntetyczne, metody analityczne, metody analityczno-syntetyczne, metody globalne (Kamińska, 2012, s. 46).

Najstarsze są metody syntetyczne, które umiejętność czytania pojmują $\mathrm{w}$ aspekcie technicznym. Celem nauki jest sprawne czytanie przez przechodzenie od elementu ${ }^{1}$ do całości. Wyróżnia się tu: metodę alfabetyczną (sylabizowanie) ${ }^{2}$, fonetyczną (głoskową) ${ }^{3}$ oraz metodę sylabową ${ }^{4}$.

Metody analityczne są przeciwieństwem syntetycznych, a ich podstawą jest przechodzenie od całości do elementu. Ważnym elementem tej metody jest połączenie analizy słuchowej $z$ analizą wzrokową i wyodrębnianie jednostek językowych, takich jak wyraz, część zdania i zdanie. Wyróżnia się zatem metody wyrazowe $^{5}$ i zdaniowe ${ }^{6}$.

Wobec obu metod były formułowane zarzuty, gdyż rozdzielały one analize i syntezę, czyli procesy niezbędne do opanowania umiejętności czytania i pisania. W odpowiedzi na te trudności powstały metody analityczno-syntetyczne. Polegają one na rozkładaniu danej jednostki (np. wyrazu) na poszczególne elementy, a następnie składanie ich w całość. Są to metody mieszane, które łączą

${ }^{1}$ Elementem może być dźwięk lub znak graficzny (litera), a całością — wyraz lub zdanie (Kamińska, 2012).

${ }^{2}$ Metoda alfabetyczna polega na poznaniu kształtu liter, po czym przystępuje się do czynności składania ich w sylaby, a następnie do tworzenia wyrazów. Czytanie rozpoczynano od procesu sylabizowania. Podstawą tej metody jest poznawanie liter w kolejności alfabetycznej (Kamińska, 2012, s. 46).

${ }^{3}$ Metoda fonetyczna opiera się na głosce, czyli dźwięku. Następnie zapoznaje się dzieci z graficznym odpowiednikiem głoski, czyli literą. Ta metoda rozwinęła się zarówno w kierunku analitycznym, jak i syntetycznym. Po opanowaniu głosek i liter następowało przejście do czynności składania dźwięków w wyrazy (Kamińska, 2012, s. 47).

${ }^{4}$ Uczenie metodą sylabową rozpoczynano od zgłosek (sylab) samogłoskowych, a następnie przechodzono do zgłosek złożonych. Opanowanie nauki czytania polega na wyodrębnianiu ze zgłosek pojedynczych liter (Kamińska, 2012, s. 48)

${ }^{5}$ Metoda ta opiera się na wprowadzaniu wyrazu bądź kilku wyrazów w połączeniu z ilustracją dźwiękową. Analiza słuchowo-wzrokowa następuje dopiero w momencie, gdy dziecko potrafi rozpoznać wyraz w tekście (Kamińska, 2012, s. 49).

${ }^{6}$ Podstawą opanowania umiejętności czytania było rozumienie tekstu składającego się ze zdań. Należało zidentyfikować wyraz jako część składową zdania. Wykorzystywano cykle zdań z ilustracjami. Każde zdanie mogło zawierać jedną nową literę (Kamińska, 2012, s. 49). 
analizę, pozwalającą dzieciom opanować umiejętność pisania (operację umysłową pozwalającą na rozbiór i rozumienie), oraz syntezę, która pomaga dzieciom w czytaniu (operację umysłową pozwalającą dokonywać rekonstrukcji i tworzyć).

Metody globalne, objęte początkowo nazwą metody doraźnego czytania wyrazów, powstały jako środek zaradczy na problemy metod syntetycznych. Globalna nauka czytania polega na zapamiętaniu postaci graficznej wyrazu, części zdania bądź zdania. W tej metodzie pomija się poznawanie poszczególnych elementów wyrazu, czyli analizę, która na późniejszym etapie służy jedynie ukazaniu różnic pomiędzy wyrazami. Metody globalne budzą wiele kontrowersji, części autorów, np. J. Melendowicz, a J. Maćkowiakowa uważa, że czytanie globalne to czynność pozorna, mechaniczna, która pozwala jedynie na stwierdzenie tożsamości wyrazów. Metody te mają jednak również swoich zwolenników, m.in. K. Kamińską oraz M. Burtowy, według których ich stosowanie zwiększa zainteresowanie dziecka słowem drukowanym, a tym samym zachęca do czytania oraz wywołuje zainteresowanie głoską i literą.

W literaturze przedmiotu można znaleźć jeszcze wiele innych metod, takich: jak metoda analityczno-syntetyczna o charakterze funkcjonalnym E. i F. Przyłubskich, metoda barwno-dźwiękowa H. Metery, metoda dobrego startu M. Bogdanowicz, wprowadzenie w świat pisma I. Majchrzak, metoda literowobarwna B. Rocławskiego (Kamińska, 2012, s. 54-81) i wiele innych.

\section{Autorska rekonstrukcja metody czytania Jürgena Reichena}

Dążąc do tego, by stać się nauczycielem profesjonalistą, próbowałam znaleźć najlepszą metodę pracy. Pogłębiałam wiedzę na temat podstaw nauki czytania i pisania, pragnąc zostać ekspertem w tej dziedzinie. Próbowałam znaleźć metodę, która będzie rekonstruować niedostatki poprzednich. W poszukiwaniu inspiracji udało mi się dotrzeć do książki Grażyny Krasowicz-Kupis pt. Rozwój świadomości językowej dziecka, w której język definiowany jest jako system dwuklasowy: pierwszą klasę stanowią symbole językowe, a drugą - reguły łączenia tych symboli właściwe dla danego języka (Krasowicz-Kupis, 2004, s. 18). Odnosi się to do rozwoju świadomości językowej dziecka, a więc świadomości istnienia symboli i reguł języka, czego przejawem jest rozmyślne używanie przez dziecko środków językowych, kontrolowanie poprawności ich wykorzystywania oraz intencjonalne manipulowanie tymi środkami (s. 19).

Zainteresowana tematyką rozwoju świadomości językowej, postanowiłam zagłębić się w jej teoretycznych założeniach. W ten sposób dotarłam do wielu ćwiczeń fonetycznych i fonologicznych, dostrzegając ich wartość w przygotowywaniu dzieci do nauki czytania i pisania. Studiując literaturę przedmiotu, sięg- 
nęłam po książkę Anny Jurek (2012) Rozwój dziecka a metody nauczania i czytania, w której zawarte są różne teorie rozwoju językowego oraz metody uwzględniające także współczesne koncepcje nauczania czytania i pisania. Tym sposobem poznałam metodę nauki czytania przez pisanie. Jest to propozycja niemieckiego autora Jürgena Reichena. Jej oryginalny tytuł to Lesen durch Schreiben. Koncepcja Reichena zakłada, że dziecko, dzięki próbom zapisywania swoich myśli przy wykorzystaniu pomocy dydaktycznych, jest w stanie opanować umiejętność czytania (Wieszczeczyńska, 2007, s. 180). W tym wypadku pomocą jest tabela nagłosowa (alfabet demonstracyjny), opracowana przez Reichena.

Autor zaznacza, że dzieci są bardziej zmotywowane do nauki pisania niż czytania, na co wskazują samodzielne, błędne próby zapisu swoich myśli już w przedszkolu. Punktem wyjścia do nauki czytania jest umiejętność zapisu języka mówionego, czyli rozłożenia danego wyrazu na głoski i zapisanie go w postaci fonetycznej. Częste wykonywanie tego rodzaju ćwiczeń prowadzi do zautomatyzowania czynności, a następnie do opanowania umiejętności czytania (s. 181). Wymaga to jednak odpowiedniego przygotowania, gdyż aby dziecko poprawnie oddzielało głoski, musi mieć dobrze rozwinięty słuch fonematyczny. Zatem pierwsze ćwiczenia przygotowujące do nauki czytania polegają na rozkładaniu wyrazu na głoski i określaniu ich kolejności w wyrazie. Dopiero po ćwiczeniach analizy i syntezy słuchowej powinno się przejść do następnych etapów nauki czytania (s. 180). Potem dziecko jest zaznajamiane $z$ tabelą nagłosową, która zawiera ułożone $\mathrm{w}$ podkowę obrazki, przedstawiające obiekty i przyporządkowane do nich litery lub połączenia liter symbolizujące głoski nagłosowe nazw tych obiektów. Dziecko analizuje wyraz i wybiera litery, odpowiadające kolejnym głoskom, z których składa się dany wyraz. Musi najpierw przeanalizować konkretny wyraz, rozłożyć go na głoski i dopiero zapisać, korzystając z tabeli (Jurek, 2012, s. 166). Poniżej przedstawiam tabelę nagłosową (alfabet demonstracyjny) J. Reichena.

Po dogłębnej analizie literatury przedmiotu oraz uzupełnieniu swojej wiedzy na temat metod dźwiękowych stwierdziłam, że metoda J. Reichena, uznawana w literaturze za eksperymentalną (Jurek, 2012, s. 165), byłaby atrakcyjną formą kształtowania świadomości fonologicznej u dzieci. Postanowiłam podjąć próbę stworzenia tabeli nagłosowej z polskimi literami, która będzie podstawą mojej pracy. Biorąc pod uwagę, że dziecko w wieku przedszkolnym uczy się spontanicznie i okazjonalnie, stworzyłam w swojej sali kącik literowy i w ten sposób dałam dzieciom przestrzeń do samodzielnego doświadczania. Według Marii Kielar-Turskiej dziecko „uczy się przez cały czas, a nie tylko wówczas, kiedy dorośli uczą je według własnego programu, wchodząc $w$ interakcje $z$ otoczeniem, konstruuje własne widzenie świata. Osoba dorosła powinna dostrzegać poznawczy zapał dziecka i spontaniczne dążenie do poznania świata. Zadaniem dorosłego byłoby podtrzymywanie dziecięcego zapału oraz wystrzeganie 


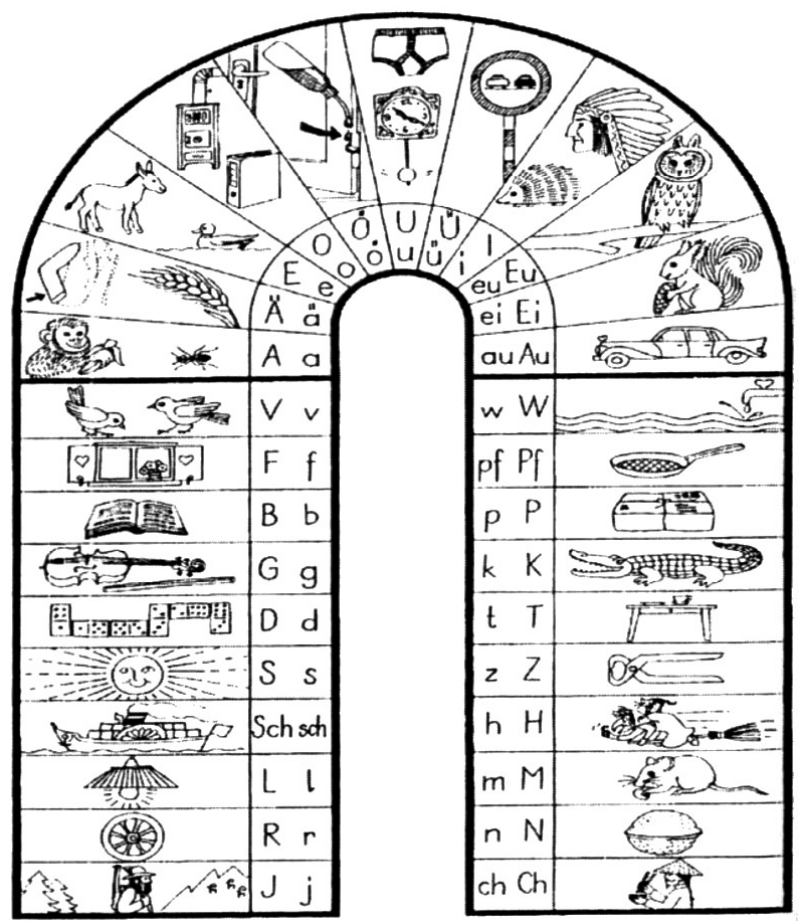

Ryc. 1. Tabela nagłosowa Jürgena Reichena. Źródło: Wieszczeczyńska 2007, s. 180

się jego stłumienia poprzez narzucanie sztywnego programu, który niszczy także własny rytm uczenia się dziecka" (1992, s. 24). Postanowiłam zatem wzbudzić u dzieci spontaniczną aktywność twórczą i zachęcić je do działań tak, aby cała sala była przestrzenią edukacyjną. W różnych częściach sali wywiesiłam wizytówki z podpisami przedmiotów, na których zostały powieszone, bądź miejsc, tzw. kącików tematycznych. Dzieci miały także podpisane krzesełka. Zauważyłam, że ich zainteresowanie literami i wizytówkami bardzo wzrosło. W czasie swobodnej zabawy podchodziły z wizytówkami i próbowały odnaleźć litery $\mathrm{w}$ tabeli nagłosowej. Zamieszczony obok litery rysunek pozwalał im na wyodrębnienie głoski i tym samym dopasowanie jej do litery.

Działania dzieci sprawiły, że postanowiłam rozszerzyć kącik literkowy i uzupełnić go o ruchomy alfabet oraz podpisane karty z obrazkami. Kącik zaczął się systematycznie zmieniać, często $z$ inicjatywy dzieci, które np. proponowały nowy wyraz rozpoczynający się na daną głoskę. Podczas swobodnej zabawy zaobserwowałam, że tabela poza walorem poznawczym, ma także duże znaczenie w rozwoju społecznym dzieci. Prowadząc codziennie obserwację, miałam możliwość być uczestnikiem wielu interakcji społecznych, które dzieją się za przyczyną pracy z moją pomocą dydaktyczną. 


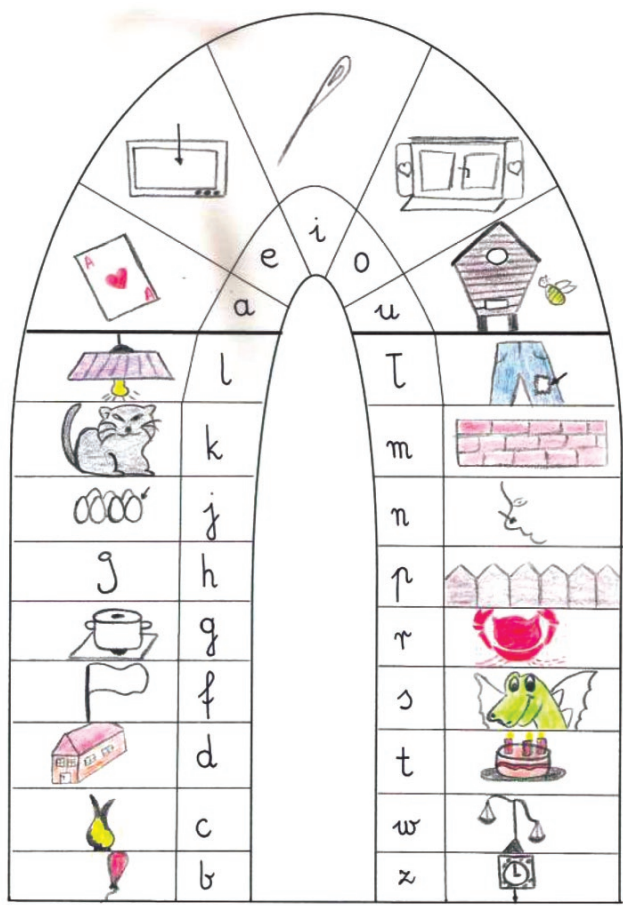

Ryc. 2. Tabela mojego autorstwa będąca podstawą kształtowania świadomości fonologicznej u dzieci. Źródło: Opracowanie własne

\section{Notatki z obserwacji prowadzonej w grupie przedszkolnej}

03.09.2018, godz. 8.00

Kiedy przyprowadziłam dzieci do sali, ich zdziwienie, radość i podekscytowanie nie miało granic. Dzień zaczęliśmy od pokazania dzieciom nowych miejsc, które pojawiły się w naszej sali, a był to kącik matematyczny, rozbudowany kącik małego badacza i kącik polonistyczny, który zwrócił największą uwagę. Na ścianie została powieszona tablica demonstracyjna przedstawiająca litery i obrazki, które prezentują wyraz rozpoczynający się na napisaną obok literę. Pod tablicą stoi stolik z kartonikiem, w którym jest ruchomy alfabet, podpisane ilustracje (takie same jak na tablicy) oraz wizytówki dzieci. Kącik zwrócił uwagę dzieci pod każdym względem - wielkości, zawartości, a także, że krzesełko przystawione do niego nie jest zgodne $z$ kolorem przewodnim naszej sali czerwonym.

Kiedy skończyłam oprowadzać dzieci po sali, jedno z nich zapytało: Pani Aniu, czy możemy pobawić się w przy tablicy z literami? Wyraziłam zgodę, choć wiedziałam, że dzieci nie wiedzą, jak mogą pracować w tym kąciku. Chłopcy 
(Gabryś, Radek i Antoś) od razu zabrali się do pracy. Radzili sobie bardzo dobrze, zaczęli od przyporządkowywania liter na tablicy do kart przedstawiających litery z alfabetu. Ku mojemu zdziwieniu chłopcy bawili się literkami aż do śniadania (zabawa trwała około $30-40 \mathrm{~min}$ ). Zajęcie ich nie znudziło, ale wzbudziło wiele pytań, np.: Faka to litera?; A dlaczego to ten rysunek?; Czy jeśli tu jest flaga, to ta litera to $f$ ?

Po śniadaniu zaprosiłam dzieci do wspólnej zabawy. Rozpoczęłam ją od powtórzenia zabaw z wizytówkami (imionami dzieci). Najpierw dzieci podzieliły swoje imiona na sylaby, a potem przywitałam się z dziećmi zabawą Czyje imię rozpoczyna się na gtoskę...?

Po ukończonej zabawie dzieci wybrały swoje wizytówki, a następnie odnajdywały na macie kolejne litery swojego imienia (stawały na literach, które odpowiadały literom z wizytówki). Coraz więcej dzieci samodzielnie nazywało litery, które zawiera ich imię (wcześniej robiłam to ja). Po zabawie na macie zaprezentowałam tablicę demonstracyjną i poprosiłam, aby każdy odnalazł taką samą literkę, jaka jest na pierwszym miejscu na jego wizytówce. Każde dziecko odpowiadało, pokazywało literę i nazywało głoskę. Następnie ułożyłam z liter swoje imię, proponując dzieciom kontynuowanie zabawy $\mathrm{z}$ wykorzystaniem własnych imion.

03.12.2018 r., zajęcia otwarte, koleżeńskie Zajęcia głównie skupiały się na eksperymentowaniu, kodowaniu oraz na pracy z robotami. Pierwszym zadaniem dzieci było odszyfrowanie zakodowanego tematu zajęć na macie. Podczas odczytywania przeze mnie współrzędnych np. Al, dzieci odkrywały litery i układały je obok siebie, nazywając je. Okazało się, że dzieci nie znają wszystkich liter potrzebnych do odgadnięcia hasła (nie byłam tym zdziwiona). Już z pierwszą literą $-P-$ pojawił się problem. Jaś, zapytany przeze mnie, co to za litera, powiedział: Nie wiem, ale moge sprawdzić. Zgodziłam się na to. Podszedł do tablicy, przyłożył kartonik do litery, która wyglądała tak samo. Zapytałam, czy to ta litera. Powiedział, że tak, ale nie wie, jak się nazywa. Zapytałam, co przedstawia obrazek. Jaś odpowiedział, że to płot, więc zadałam pytanie: A co styszysz na początku wyrazu „płot”. Jaś: No, p. Ja: Więc jaka to litera? Jaś: No, tė̇ $P$. Tym sposobem doszliśmy do tego, jak nazywa się pierwsza litera. Byłam bardzo zadowolona, że Jaś sam zaproponował tablicę jako pomoc.

Analogicznie do litery $\mathrm{P}$ odkryliśmy wszystkie litery. Nie było problemu z literami O, A. Sytuacja powtórzyła się jednak przy literze G i D. Literę G odszyfrowała Oliwka, która bardzo dużo samodzielnie pracuje z tablicą, więc odnajdując na tablicy tak samo wyglądającą literkę, od razu ją nazwała. U Oliwki już bardzo dobrze rozwinął się słuch fonematyczny, poza tym jej myślenie przyczynowo-skutkowe jest również bardzo dobrze rozwinięte, więc od razu wie- 
działa, co zrobić z literką i jak powiązać ją z głoską. Z literką $\mathrm{D}$ był niewielki problem - Lena podeszła do tablicy, ale nawet nie musiała długo szukać litery, gdyż poznaliśmy ją już wcześniej. Zobaczyła tylko obrazek domu i od razu wiedziała, jak nazwać literę. W ten sposób udało nam się ułożyć wyraz POGODA. Następnie przegłoskowałam go i zapytałam, czy dzieci wiedzą, co powiedziałam. Jest to długi wyraz, wziąwszy pod uwagę właśnie ten etap rozwijania świadomości fonologicznej, lecz niektórym dzieciom udało się go odgadnąć.

Dzieci dość dobrze poradziły sobie z tym zadaniem, które było połączone z inną aktywnością - kodowaniem i odczytywanie współrzędnych. Dzieci były aktywne i chętnie się zgłaszały. Trudność przy tego typu zadaniach zawsze polega na tym, że $w$ ich rozwiązywaniu mogą wziąć czynny udział tylko dzieci wybrane przez nauczyciela. Pozostali jednak pomagają, czasami wyrywając się do odpowiedzi. Dzieci już dobrze sobie radzą z tablicą demonstracyjną, więc w takich przypadkach sobie pomagają i tak było tym razem. Kiedy jedno nie może znaleźć litery bądź nie potrafi jej odgadnąć, zaraz któryś z kolegów podpowiada: Popatrz na obrazek!; Co tam jest?; Na co się zaczyna?

30. 01.2019 r., godz. 14.20, zabawa swobodna dzieci Po powrocie z obiadu dzieci mają czas na zabawę swobodną. Gabryś, Filip i Maja siadają do stolika z literkami. Biorą karty z podpisami i ruchomy alfabet. Układają literki pod podpisami i próbują odczytać wyrazy: PŁOT, KOT, LAMPA, AS, UL, NOS, TORT, RAK. Dzieci próbują odczytać wyrazy. Trudność mają z odczytaniem słów AS oraz UL. Głoskują po kolei: To jest $A, A$ to jest SY, czyli mamy asy. Filip mówi: Ale tu nie ma SY, tylko S. Pani nam kiedyś mówita, pamiętacie? Gabryś: Ale $S$ to ta sama litera! Odpowiada mu Filip: Ale as jest jeden, a asy dwa!. W tym momencie podeszłam do dzieci i wytłumaczyłam im różnicę, mówiąc, że nie wymawia się głoski $s$ jako sy, lecz krótko - $s$. Po czym ułożyłam dzieciom $z$ alfabetu ruchomego wyrazy AS i ASY. Na tej samej zasadzie wyjaśniłam różnicę pomiędzy wyrazami UL i ULE. Wyjaśniłam dzieciom, że nie ma głoski $l e$ ani $e l$, należy krótko powiedzieć $l$. Dzieci ułożyły z alfabetu ruchomego słowa UL i ULE. Wytłumaczyłam, że są to dwa różne wyrazy, ponieważ ul jest jeden, a ule są dwa.

\section{Dyskusja}

Podejmując refleksję nad wybranymi notatkami z obserwacji pedagogicznej, można rozważać wiele aspektów. Przede wszystkim jej skuteczność bądź nieskuteczność w kształtowaniu świadomości fonologicznej, a co za tym idzie w przygotowaniu dzieci do nauki czytania i pisania, a także jej walory społeczne, czy też kwestie rozwoju zawodowego nauczyciela. Zacznę jednak od najważ- 
niejszej kwestii, czyli poznawczego aspektu wprowadzanej przeze mnie innowacji. Codzienne obcowanie dzieci z głoskami i literami pozwala im na naturalne wchodzenie w świat czytelnictwa oraz pobudza zainteresowania nim. Odbywa się to nie podczas lekcji pokazowych, wykładu, rozmowy, pogadanki, ale w czasie własnej aktywności dzieci. Zainteresowanie to było widoczne na każdym etapie wprowadzenia przeze mnie tabeli nagłosowej - nie tylko na początku, ale także pod koniec roku szkolnego, przez co można wykluczyć, iż zainteresowanie było wynikiem efektu nowości, zamiast atrakcyjności. Kącik literowy to było miejsce nauki nie tylko podczas zajęć, które zawsze odbywały się $\mathrm{w}$ formie zabawy, ale przede wszystkim podczas zabaw swobodnych, rówieśniczych dzieci. Stawianie pytań sobie, rówieśnikom czy też nauczycielowi dawało im poczucie sprawczości własnej edukacji.

Zmiany ilustracji w czasie roku szkolnego miały na celu stopniowanie trudności oraz zapobiegały pamięciowemu zapamiętywaniu graficznego znaku, jakim jest litera, i odpowiadającej jej głoski. Zgodnie z zasadami języka polskiego na pierwszych kartach pojawiały się ilustracje, które można opisać w formie trzyliterowych wyrazów bez dwuznaków i zmiękczeń. Następnie wprowadzane były słowa cztero- i pięcioliterowe. Korzystanie $\mathrm{z}$ alfabetu ruchomego pozwalało dzieciom na podejmowanie próby analizy i syntezy literowej oraz głoskowej.

Chciałabym w tym momencie odpowiedzieć na postawione mi kiedyś pytanie, czym różni się mój sposób przygotowania dzieci do nauki czytania od innych, obowiązujących metod. Uważam, że zaletą tej metody jest stworzenie uczniom możliwości samodzielnego obcowania $z$ literami w dowolnym momencie pobytu w przedszkolu. Nie polega to, tak jak w wielu innych przedszkolach, na obcowaniu $z$ obrazkiem i znakiem graficznym jednego wyrazu, który reprezentuje daną literę (na przykład $o$ jak oko), ale daje dzieciom możliwość poszukiwania różnych wariantów odpowiadających konkretnej literze oraz dokonywania analizy nie tylko w nagłosie, ale także w śródgłosie i wygłosie wyrazu, a także dokonywania analizy i syntezy literowej bądź głoskowej.

Podczas zabaw swobodnych, rówieśniczych, ale także podczas zajęć, praca $\mathrm{z}$ tabelą nagłosową daje dzieciom przestrzeń do współpracy i dyskusji na temat kwestii spornych. Pozwala to kształtować u dzieci umiejętności komunikacyjne, a także umiejętność rozwiązywania problemów. Ponadto można tu przywołać teorię tutoringu rówieśniczego (Sławińska, 2015, s. 41-56), która jest doskonałym przykładem transmisji wiedzy i doświadczenia między dziećmi. W przypadku grupy mieszanej pięcio- i sześciolatków, z którą pracowałam, ta teza tym bardziej się potwierdza. Przestrzeń edukacyjną stworzyła właśnie tablica literowa, która stała się miejscem spotkań dzieci, w którym rozstrzygane były wątpliwości, trudności, a nawet problemy. Kolejnym ważnym zjawiskiem była pomoc starszaków świadczona pięciolatkom, 
poszukiwanie wiedzy u innych dzieci w przypadku niepewności oraz angażowanie nauczyciela. Praca przy tabeli wzbudzała u dzieci wiele emocji, pozwalała im na doświadczanie nie tylko wrażeń poznawczych, ale i uczyła, że niewiedza nie jest powodem do wstydu, lecz pomaga eksplorować najbliższe otoczenie.

Warto też skupić się na osobie nauczyciela, który mimo pozornie biernego udziału w całym procesie kształtowania świadomości fonologicznej jest bardzo ważnym uczestnikiem interakcji. Analizując dziennik obserwacji, można wnioskować, że nauczyciel jest dla dzieci źródłem wiedzy pewnej, daje im poczucie bezpieczeństwa i potwierdzenia ich pomysłów. $Z$ tego powodu musi on mieć odpowiednie przygotowanie merytoryczne i metodyczne na temat rozwijania świadomości fonologicznej, znać specyfikę języka polskiego oraz zasady wprowadzania dzieci w świat języka. Ponadto nauczyciel jest także inicjatorem zabaw, które następnie są modelowane podczas zabawy swobodnej. Można więc wnioskować, że praca $\mathrm{z}$ tabelą daje nauczycielowi możliwość obserwacji dzieci, ich postępów, trudności oraz odpowiedniej reakcji bądź zorganizowania sytuacji dydaktycznej odpowiadającej indywidualnym potrzebom dziecka. Poza sferą poznawczą nauczyciel ma także możliwość obserwacji dzieci podczas nawiązywania przez nie kontaktów społecznych.

Należy także zastanowić się nad wpływem opisywanych sytuacji na osobę samego nauczyciela. Sytuacje dydaktyczne, organizowane przeze mnie bądź przez dzieci, spowodowały, że zaczęłam się zastanawiać nad sensem własnych działań i ich wpływem na mnie oraz moją grupę. Przede wszystkim, mimo początkowych trudności $z$ wprowadzeniem innowacyjnych działań i sprzeciwu swoich współpracowników, zauważyłam, że moja praca przynosi pozytywne efekty. Dla dzieci jest źródłem nowego doświadczenia, które nie tylko pozwala przygotować się do podjęcia nauki w szkole, ale także przygotowuje je do aktywnego funkcjonowania $\mathrm{w}$ otaczającym świecie. Jest źródłem wiedzy o dzieciach, ale także o mnie. Widząc własne zaangażowanie w stworzenie „nowej” przestrzeni edukacyjnej, a także końcowe efekty, zrozumiałam, że właśnie taka praca nauczyciela daje mi poczucie satysfakcji, spełnienia oraz pewność, że moje działania są prawidłowe.

Rzeczywistość edukacyjna, w której się znalazłam, skłoniła mnie do refleksji na temat mojej roli w edukacji. Edukacja dzieci, zarówno w przedszkolu, jak i w szkole, ujmowana jest $\mathrm{w}$ jednym $\mathrm{z}$ trzech podstawowych wzorów:

- edukacji o tradycyjnej strukturze (traditional structured education): opiera się na bezrefleksyjnym przyjmowaniu wiedzy jedynej i prawdziwej, a nauczanie jest normatywne;

- edukacji półstrukturalnej (semi-structured education), w której doświadczenia edukacyjne są $\mathrm{w}$ pewnym stopniu planowane, a procesy poznawcze są organizowane w określonych strukturach; 
oraz

— edukacji progresywnej (progressive, „free"” education), czyli edukacji wolnej, zorientowanej praktycznie i niemożliwej do zaplanowania (PerkowskaKlejman, 2003, s. 77).

Mając na uwadze sposób mojej pracy, stwierdzam, że moje działania i organizowanie doświadczeń edukacyjnych najbardziej tożsame są z edukacją półstrukturalną, ponieważ ich podstawą jest uczenie przez doświadczanie, a nie bezkrytyczne organizowanie procesów poznawczych i przyjmowanie gotowej wiedzy. Podstawy moich założeń i refleksyjność odnoszą się nie tylko do mnie jako nauczyciela, ale także do dzieci, a zatem nie wpisują się w ramy teoretyczne edukacji progresywnej, ponieważ ta jest całkowicie wolna i zależna od uczniów. Przyjęłam postawę nauczyciela-refleksyjnego praktyka (Lasek, Piątek, 2005, s. 91-92). Według Eve Malmquist aktywność własna nauczyciela wzbudza u dzieci aktywność twórczą, a nauczanie czytania dzieci w wieku przedszkolnym nie powinno koncentrować się na wybranej przez niego metodzie, lecz na wspomaganiu dziecka, co jest rozumiane jako „stworzenie dziecku właściwych warunków umożliwiających opanowanie umiejętności czytania [...], nieprzeszkadzanie mu $\mathrm{w}$ prawidłowym rozwoju zgodnym $\mathrm{z}$ indywidualnym tempem i rytmem" (Kamińska, 2012, s. 84-85). K. Kamińska określa ten warunek jako tworzenie sytuacji samodzielnego dochodzenia do rozwiązania na własny indywidualny sposób. Nauczyciel w tym wypadku przyjmuje na siebie wiele ról: inspiratora, organizatora warunków do własnej aktywności, obserwatora, ale przede wszystkim osoby, która respektuje prawo dziecka do ciągłego, swobodnego i harmonijnego rozwoju. Autorka ta podkreśla, że w edukacji przedszkolnej nie zawsze przestrzega się tego prawa dziecka. Jako młody, czynny nauczyciel mogę potwierdzić tę tezę. Zastanawiając się nad obecnym stanem polskiej edukacji przedszkolnej, obserwowanej podczas praktyk i stażów, postanowiłam, że nie chce być kolejnym nauczycielem, który prowadzi swoją grupę, przekazując jej gotową wiedzę, czyli stosuje edukację o tradycyjnej strukturze. Według sugestii Danuty Waloszek „nie można dziecku narzucać $z$ góry tego, co będzie robiło w przedszkolu - w jaki sposób, w jakim czasie, z wykorzystaniem jakich środków i materiałów" (Kamińska, 2012, s.84-85). Postanowiłam więc wyeliminować bądź znacznie zmniejszyć liczbę sytuacji, których przebieg jest ściśle zaplanowany i nie uwzględnia stanowiska dziecka na rzecz stworzenia bogatej w różnorodne propozycje przestrzeni edukacyjnej, która pozwoli na ich wszechstronny rozwój. 


\section{Podsumowanie}

Tablica demonstracyjna jest autorską pomocą dydaktyczną wykorzystywaną podczas kształtowania świadomości fonologicznej. Początkowo interesowała mnie głównie skuteczność samej metody, jednak w trakcie wprowadzania tej nieznanej dzieciom pomocy zauważyłam wiele interesujących zjawisk społecznych. Zaczęły mnie ciekawić reakcje dzieci na wprowadzenie tablicy oraz wpływ tych reakcji na moje postępowanie, samoświadomość, a także problemy $\mathrm{z}$ tym związane oraz sposoby radzenia sobie $\mathrm{z}$ nimi.

W przypadku młodych nauczycieli samoświadomość i refleksyjność są bardzo ważne, lecz tradycyjny system edukacji raczej koncentruje się na uniwersalnych metodach pracy, co często powoduje wejście w schematy. Poznanie i wyjaśnienie motywów działań, które wpływają na mój rozwój zawodowy i profesjonalizację zawodu nauczyciela, może być przykładem $\mathrm{z}$ codziennego życia nauczycieli i inspiracją do zmiany swojego postępowania dla innych młodych nauczycieli. Kategoria zmiany nie wiąże się z koniecznością wprowadzania innowacji, ale $\mathrm{z}$ przyjmowaniem postawy aktywnego i refleksyjnego praktyka. Wymaga to od nauczyciela dokonania wnikliwej analizy zalet i wad wprowadzania innowacji oraz ich konsekwencji dla dzieci, a także dla niego samego.

\section{Bibliografia}

Gerlach, R. (2014). Rozwój zawodowy jako element całożyciowego rozwoju człowieka, „Polityka Społeczna", nr 3, s. 3-6.

Gołębniak, G. D. (1998). Zmiany edukacji nauczycieli. Wiedza, biegłość, refleksyjność. Edytor, Toruń.

Jurek, A. (2012). Rozwój dziecka a metody nauczani czytania i pisania. Gdańsk: Harmonia Universalis.

Kamińska, K. (2012). Nauka czytania dzieci w wieku przedszkolnym. Warszawa: WSiP.

Kielar-Turska, M. (1992). Fak pomagać dziecku w poznawaniu świata. Warszawa: WSiP.

Krasowicz-Kupis, G. (2004). Rozwój świadomości językowej dziecka. Lublin: Wyd. UMCS.

Lasek, E. I., Piątek T. (2005). Wokót zintegrowanego kształcenia uczniów w młodszym wieku szkolnym. Rzeszów: Wyd. URz.

Marek, E. (2003). O pomyślny start ucznia w szkole. „Życie Szkoły”, nr 1, s. 56-60.

Perkowska-Klejman, A. (2003). Modele refleksyjnego uczenia się. „Teraźniejszość - Człowiek — Edukacja”, nr 1 (61), s. 75-90.

Sławińska, M. (2015). Tutoring rówieśniczy w edukacji, czyli jak uczniowie ucza się od siebie wzajemnie $i$ co z tego wynika. „Forum Oświatowe”, 27 (2), s. 41-55.

Wieszczeczyńska, E. (2007). Wczesnoszkolna edukacja językowa a nauczanie czytania. Program alfabetyzacji w języku niemieckim jako obcym na przykładzie wybranych metod i elementarzy: Wrocław: Oficyna Wydawnicza ATUT. 